\title{
Evaluation of Efficacy of Oxytetracycline Oral and Bath Therapies in Nile Tilapia, Oreochromis niloticus against Aeromonas hydrophila Infection
}

\author{
R. Beryl Julinta ${ }^{1}$, Anwesha Roy ${ }^{1}$, Jasmine Singha ${ }^{1}$, T. Jawahar Abraham ${ }^{1 *}$ and P.K. Patil ${ }^{2}$ \\ ${ }^{1}$ Department of Aquatic Animal Health, Faculty of Fishery Sciences, West Bengal University of \\ Animal and Fishery Sciences, Chakgaria, Kolkata - 700 094, West Bengal, India \\ ${ }^{2}$ Central Institute of Brackishwater Aquaculture, Indian Council of Agricultural Research, Raja \\ Annamalai Puram, Chennai - 600028, Tamil Nadu, India \\ *Corresponding author
}

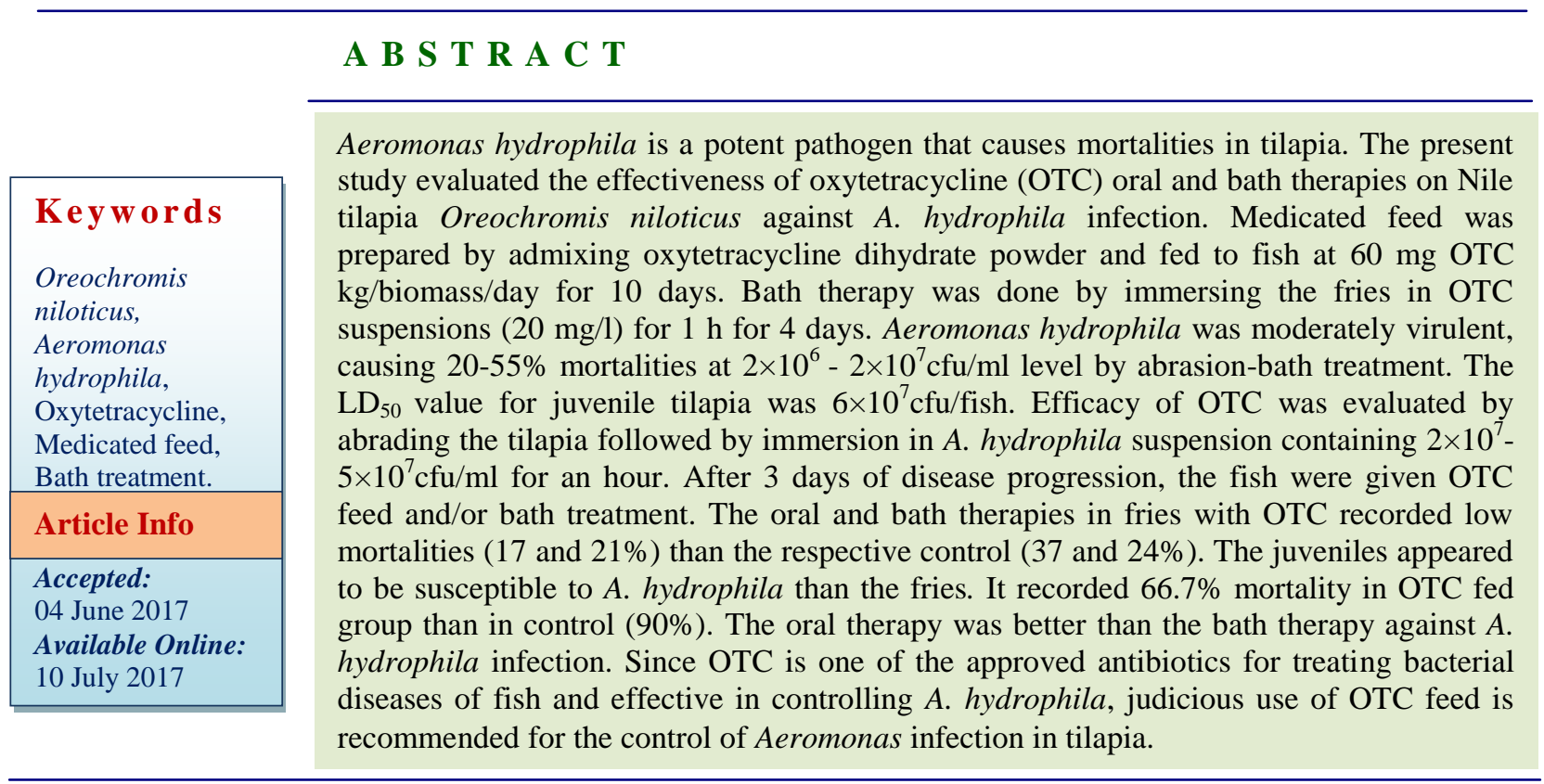

\section{Introduction}

Tilapia is one of the most important cultured fish and currently ranks second after carps in global production (FAO, 2012).

Tilapias have long been considered as an ideal species for use in aquaculture due to its hardy nature, fast growth, tolerance of suboptimal water quality and disease resistance (Little et al., 2008). Nile tilapia Oreochromis niloticusis considered as the most important farmed tilapia species, representing $>73 \%$ of total tilapia production in 2010 (FAO, 2012). Diseases are one of the major problems that affect the tilapia production. Bacterial diseases have become major barriers to aquaculture, especially when water temperature is warm. Aeromonas hydrophila is an opportunistic as well as primary pathogen of variety of aquatic and terrestrial animals including man. The presence of A. hydrophila, by itself, is not indicative of disease and, consequently, stress is often 
considered to be a contributing factor in the outbreak of disease caused by this bacterium (Goharrizi et al., 2015). Aeromonas septicemia was reported in tilapia culture (Noga, 2010; Austin and Austin, 2012; Noor El-Deen et al., 2014). Elevated water temperature, decreased dissolved oxygen concentration, or increased ammonia and carbon-dioxide concentrations have been shown to promote stress in fish and trigger motile aero monads infection (Noga, 2010; Austin and Austin, 2012)

A wide variety of aquadrugs are used to control the diseases caused by bacteria, fungi, parasites and viruses (Hernandez, 2005; Noga, 2010; Austin and Austin, 2012). Oxytetracycline (OTC) is one of the USFDA (United States Food and Drug Administration) approved chemotherapeutics for treating specific bacterial diseases in temperate and warm water finfish(FDACVM,2007). It is particularly effective against Gram-negative bacteria such as Vibrio spp., Aeromonas spp. and Pseudomonas spp. (Austin and Austin, 2012). Reports on the efficacy of OTC to control specific bacterial diseases in temperate condition are available (Schmidt et al., 2007; Austin and Austin, 2012; Romero et al., 2012).

But, its efficacy on cultured fish under the tropical Indian condition is poorly documented. Often OTC is used in Indian aquaculture (Hatha et al., 2005; Bharathkumar and Abraham, 2011) without veterinary prescriptions. The effectiveness and safety of a drug before approval requires a scientific evaluation by USFDA in USA. Also, the USEPA (United States Environmental Protection Agency) requires a scientific evaluation of a chemical's safety before it can be registered and sold (FDACVM, 2007). There appears to be no regulation on the use of OTC in Indian aquaculture. Also the efficacy and safety levels of the FDA approved antibiotics including OTC on fish cultured in India are not established. This study was, therefore, aimed at to evaluate the effectiveness of OTC feed and bath treatments on $O$. niloticus against $A$. hydrophila infection.

\section{Materials and Methods}

\section{Bacterial strain and experimental fish}

The $\beta$-haemolytic bacterial strain Aeromonas hydrophila $\mathrm{BBT}_{4} \mathrm{~K}_{3}$, isolated from the kidney of haemorrhagic septicemic Nile tilapia Oreochromis niloticus, was from the collections of the Department of Aquatic Animal Health, Faculty of Fishery Sciences (FFSc), West Bengal University of Animal and Fishery Sciences, Kolkata, India. The identity of this strain was confirmed phenotypically by Vitek 2 compact system (bioMérieux, France). Healthy monosex(all male) O. niloticus fries (weight: $1-2 \mathrm{~g}$; length: 2.3-3.0 $\mathrm{cm}$ ) and juveniles (weight: $8.2-18.0 \mathrm{~g}$; length:8.2-11.5 $\mathrm{cm}$ ) were brought from Naihati, North 24 Parganas district, West Bengal, India in oxygen filled polythene bags to FFSc, Kolkata as and when required. The fish were acclimatized for $3 \mathrm{~h}$ followed by disinfection with $5 \mathrm{ppm}$ potassium permanganate for $15 \mathrm{~min}$. The fries and juveniles were stocked in 500 litre capacity fiberglass reinforced plastic (FRP) tanks respectively at 200 and 75 numbers/tank containing 400 litre clean bore well water. The fish were acclimatized for about two weeks and fed ad-labitum with commercial pellet basal feed (CP Pvt. Ltd., Andhra Pradesh, India) at $2 \%$ body weight (bw).

\section{Pathogenicity of Aeromonas hydrophila $\mathrm{BBT}_{4} \mathrm{~K}_{3}$}

\section{Preparation of bacterial cell suspension}

Aeromonas hydrophila, maintained on TSA slant, was streaked onto TSA plate and then incubated at $35^{\circ} \mathrm{C}$ for $24 \mathrm{~h}$ to get young 
culture. One young discrete colony of this strain was aseptically picked, transferred to 10 $\mathrm{ml} \mathrm{TSB}$ and incubated at $35^{\circ} \mathrm{C}$ for $24 \mathrm{~h}$. This $24 \mathrm{~h}$ old culture was then transferred to 300 $\mathrm{ml} \mathrm{TSB}$ and reincubated at $35^{\circ} \mathrm{C}$ for $30 \mathrm{~h}$. The cells were harvested by centrifugation at 7500 $\mathrm{rpm}$ for $20 \mathrm{~min}$ at $25^{\circ} \mathrm{C}$ in a cooling centrifuge.

The cell pellets were washed thrice by centrifugation with sterile physiological saline $(0.85 \% \mathrm{NaCl})$ and finally resuspended in 10 $\mathrm{ml}$ saline, and used immediately.

A portion of the cell suspension was suitably diluted up to $10^{-9}$ in sterile saline and the number of cells $/ \mathrm{ml}$ of suspension was determined by spread plating on TSA after incubation at $35^{\circ} \mathrm{C}$ for $24 \mathrm{~h}$ (Collins et al., 2004).

\section{Pathogenicity on Oreochromis niloticus} fries by abrasion-bath treatment

The healthy O.niloticus fries were selected and released into the glass aquaria $(n=8)$ of

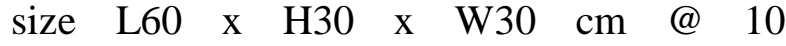
fish/aquarium and acclimatized for 5 days. All the aquaria were filled with $30 \mathrm{~L}$ clean borewell water and covered with nylon netting for adequate protection. Prior to challenge, the fish were anesthetized with clove oil $(50 \mu \mathrm{l} / 1$ water). The scales of fish from aquaria 1-6 were scrapped off gently with a scalpel from caudal peduncle to the pectoral fin, i.e., in the opposite direction (abraded) as described in Adikesavalu et al., 2015). The abraded fish from aquaria 1-2 and 3-4 were then immersed in $1000 \mathrm{ml}$ suspension containing $A$. hydrophila at $2 \times 10^{7} \mathrm{cfu} / \mathrm{ml}$ and $2 \times 10^{6} \mathrm{cfu} / \mathrm{ml}$ for $1 \mathrm{~h}$, respectively. The abraded fish of aquaria 5-6 were dipped in $0.85 \%$ saline instead of bacterial suspension for $1 \mathrm{~h}$ and served as positive control. The fish of aquaria 7-8 were neither abraded nor challenged and served as negative control.
Pathogenicity on Oreochromis niloticus juveniles by intraperitoneal injection

Pathogenicity of $A$. hydrophila $\mathrm{BBT}_{4} \mathrm{~K}_{3}$ on $O$. niloticus juveniles (weight: $15.3 \pm 2.1 \mathrm{~g}$; length: $9.2 \pm 1.1 \mathrm{~cm})$ was tested by intraperitoneal injection method. Twelve numbers of glass aquaria (Size: L60 $\times \mathrm{H} 30$ $\times \mathrm{W} 30 \mathrm{~cm})$ were selected, disinfected, cleaned, filled with 30 litre clean bore-well water after 7 days of drying, and conditioned for 3 days. All the tanks were stocked with 10 fish each and covered with nylon netting for adequate protection. After 3 days of acclimatization, aliquots $(0.1 \mathrm{ml})$ of $A$. hydrophila cell suspensions from $10^{0}$ to $10^{-4}$ dilutions were injected intraperitoneally, i.e., in the abdomen at a $45^{\circ}$ angle between the pelvic fins and anal vent, in such a way so as to get $10^{8}-10^{4} \mathrm{cfu} / \mathrm{fish}$. Control fish received $0.1 \mathrm{ml}$ of sterile saline.

The challenged fish were maintained in their respective tanks for 28 days and fed daily with commercial pellet basal feed on demand. Observations on mortality, external signs of infections and behavioural changes were recorded daily. The lethal dose at which $50 \%$ of the experimental populations die $\left(\mathrm{LD}_{50}\right)$ was calculated by standard method (Reed and Muench, 1938).

\section{Antibiogram of Aeromonas hydrophila $\mathrm{BBT}_{4} \mathrm{~K}_{3}$}

Sensitivity of A. hydrophila against 12 antibiotics namely amoxyclav (30 $\mu \mathrm{g} / \mathrm{disc})$, chloramphenicol (30 $\mu \mathrm{g} / \mathrm{disc})$, ciprofloxacin (5 $\mu \mathrm{g} /$ disc), clindamycin (2 $\mu \mathrm{g} / \mathrm{disc})$, cotrimoxazole $(25 \mu \mathrm{g} / \mathrm{disc})$, erythromycin (15 $\mu \mathrm{g} /$ disc $)$, gatifloxacin $(5 \mu \mathrm{g} /$ disc $)$, gentamicin (10 $\mu \mathrm{g} /$ disc), nitrofurantoin (300 $\mu \mathrm{g} / \mathrm{disc})$, oxytetracycline (30 $\mu \mathrm{g} /$ disc), sulphafurazole (300 $\mu \mathrm{g} /$ disc) and vancomycin $(30 \mu \mathrm{g} /$ disc $)$ was tested by agar disc diffusion technique (CLSI, 2006a) on Mueller Hinton agar (MHA) at $35^{\circ} \mathrm{C}$. Interpretation of sensitivity 
was based on the zone size interpretation chart provided by the manufacturer of the discs (HiMedia, India).

\section{Determination of minimal inhibitory concentration (MIC) and minimal bactericidal concentration (MBC) of OTC by broth dilution and tetracycline Ezy MIC $^{\mathrm{TM}}$ strip}

The MIC of OTC was determined against $A$. hydrophila $\mathrm{BBT}_{4} \mathrm{~K}_{3}$ by broth dilution (CLSI, 2006b) and Tetracycline Ezy MIC $^{\mathrm{TM}}$ strip (HiMedia, India) methods (CLSI, 2012).

\section{Broth dilution method}

The OTC dihydrate powder (HiMedia, India) was initially dissolved in $0.85 \%$ saline at concentrations 1000 times higher than the most concentrated level to be tested. Various concentrations $(\mu \mathrm{g} / \mathrm{ml})$ tried for MIC determination was $100,50,25,12.5,6.25$, $3.13,1.56,0.78,0.39,0.2,0.1$ and 0 .

The MHB with or without antibiotics at varying concentrations were inoculated with 2 $\mu \mathrm{l}\left(\sim 10^{4}-10^{5}\right.$ cells $)$ from $10-12 \mathrm{~h}$ old culture grown in $\mathrm{MHB}$ at $35^{\circ} \mathrm{C}$. All the tubes were incubated at $35^{\circ} \mathrm{C}$ for $24 \mathrm{~h}$ and observed for turbidity by comparing them with the control tube, i.e., growth or no growth.

The MIC was determined as the minimum concentration $(\mu \mathrm{g} / \mathrm{ml})$ showing no growth or turbidity at $24 \mathrm{~h}$. To determine the MBC, the tubes that showed no growth or turbidity at 24 $\mathrm{h}$ were taken.

The inocula from these tubes were streaked onto MHA plates and incubated at $35^{\circ} \mathrm{C}$ for $24 \mathrm{~h}$. The MBC was determined as the minimum concentration $(\mu \mathrm{g} / \mathrm{ml})$ showing no growth at $35^{\circ} \mathrm{C}$ when incubated overnight (CLSI, 2006b).

\section{Tetracycline Ezy MIC ${ }^{\mathrm{TM}}$ strip method}

The pure culture of A. hydrophilawas inoculated into $\mathrm{MHB}$ and incubated at $35^{\circ} \mathrm{C}$ for $6 \mathrm{~h}$. Inoculum from MHB was spread onto MHA plate using a sterile cotton swab. After 15 min, a single Tetracycline Ezy MIC $^{\mathrm{TM}}$ strip was placed onto the seeded agar plate at a desired position. The plate was incubated at $35^{\circ} \mathrm{C}$ for $18-24 \mathrm{~h}$ and observed for the zone of inhibition in the form of an ellipse. If the ellipse intersects the strip in between two dilutions, the MIC is read as the value which is nearest to the intersection. When the growth occurred along the entire strip, the MIC value is greater than the highest values on the strip. When the inhibition ellipse is below the strip, the MIC value is less than the lowest value on the strip (CLSI, 2012).

\section{Evaluation of efficacy of OTC therapy}

\section{Abrasion, bacterial challenge and OTC oral therapy in tilapia fries}

As per FDA, the approved dose of OTC is 2.50-3.75 g/100 pounds body weight (bw)/day (or $55-83 \mathrm{mg} / \mathrm{kg}$ biomass/day) for 10 consecutive days (FDA-CVM, 2007). The OTC feed was prepared by admixing required quantity of OTC dihydrate powder (HiMedia, India) in $1 \mathrm{~kg}$ of basal feed with $5 \mathrm{ml}$ of vegetable oil to get a desirable concentration of $60 \mathrm{mg} / \mathrm{kg}$ biomass/day(FDA-CVM, 2007) when fed at $3 \%$ bw. The top dressed feed was mixed thoroughly, dried under the fan for 24 $\mathrm{h}$ and then placed in a clean and dry container with a tight-fitting lid. The control feed was prepared as above without OTC. The experiment was carried out in plastic tanks of size (L58 cm $\times \mathrm{H} 45 \mathrm{~cm} \times \mathrm{B} 45 \mathrm{~cm}$ ) with mono sex O. niloticus fries (weight: $1.1 \pm 0.1 \mathrm{~g}$; length: $3.0 \pm 0.3 \mathrm{~cm}$ ). The fish were stocked @ 40 fish/tank and fed with basal feed at $3 \%$ bw. About $50 \%$ of the water was exchanged and waste feed and faecal materials were removed 
daily. The water quality parameters were maintained optimally (Water temperature: 18.0-23.5 ${ }^{\circ} \mathrm{C}$; $\mathrm{pH}$ : 7.7-8.7: dissolved oxygen: 3.5-5.1ppm and nitrate and ammonia: <0.02 ppm) throughout the experiment. The experimental fish were divided into 4 groups, namely group 1: non-abraded and unchallenged (negative control), group 2: abraded, unchallenged and control feed fed (positive control), group 3: abraded, challenged and control feed fed, and group 4: abraded, challenged and OTC feed fed. After acclimatization for 5 days, the fish from groups 2, 3 and 4 were abraded as described earlier (Adikesavalu et al., 2015). The abraded fish from groups 3 and 4 were then dipped in $1000 \mathrm{ml}$ solution containing $A$. hydrophila at $5 \times 10^{7} \mathrm{cfu} / \mathrm{ml}$ for $1 \mathrm{~h}$. The abraded fish of group 2 were dipped in $0.85 \%$ saline instead of bacterial suspension for $1 \mathrm{~h}$ and served as positive control. All the fish after the dip in bacterial cell suspension/saline were transferred to the respective tanks. The fish of groups 1-3 were fed with control feed at $3 \%$ bw throughout the experimental period twice daily. The fish of group 4 were fed with control feed during the pre-treatment (1-5 days) and disease progression (6-8 days) periods. During the treatment period for 10 days (9-18 days), they were fed with OTC feed at $3 \%$ bw twice daily, equivalent to 60 $\mathrm{mg} / \mathrm{kg}$ biomass/day. During the posttreatment period for 21 days (19-39 days), the fish were fed with control feed. Observations on mortality, external signs of infections and behavioural changes were recorded daily.

\section{Abrasion, bacterial challenge and OTC bath therapy in tilapia fries}

The FDA-approved dose of OTC bath treatment (immersion therapy) is $20 \mathrm{mg} / \mathrm{l}$ of water for $1 \mathrm{~h}$ for 4 days to control the mortality caused by bacterial diseases (WGADCB, 2011). The experiment was carried out in plastic tanks of size (L58 $\times$ H45 $\times$ B45 cm) with mono sex O. niloticus fries (weight: $1.1 \pm 0.1 \mathrm{~g}$; length: $3.0 \pm 0.3 \mathrm{~cm}$ ). The fish were stocked @ 35 fish/tank and fed with basal feed at $3 \%$ bw. About $50 \%$ of the water was exchanged and waste feed and faecal materials were removed daily. The water quality parameters were maintained optimally throughout the experiment. The grouping of fish and treatment protocols were as described above, except the mode of OTC treatment. The abraded fish from groups 3 and 4 were then dipped in $1000 \mathrm{ml}$ solution containing $A$. hydrophila at $2.0 \times 10^{7} \mathrm{cfu} / \mathrm{ml}$ for $1 \mathrm{~h}$, and transferred to the respective tanks. Three days post-abrasion and challenge, the fish of group 4 (abraded and challenged) were given an OTC bath as below. In brief, the OTC bath suspension was prepared by dissolving appropriate quantities of OTC hydrochloride powder (Terramycin ${ }^{\circledR} 500 \mathrm{mg}$, Pfizer, Bangalore). The abraded fish of group 4 were transferred to the treatment troughs with 3 litre water containing $20 \mathrm{mg}$ OTC/1 and allowed to remain in the troughs for $1 \mathrm{~h}$. After the bath treatment, the fish were transferred to the respective tanks. This treatment was continued for 4 consecutive days. The fish were fed with basal feed twice daily at $3 \%$ bw during the entire study period (1-33days). Observations on mortality, external signs of infections and behavioural changes were recorded daily.

\section{Abrasion, bacterial challenge and OTC oral therapy in tilapia juveniles}

The experiment was carried out in plastic tanks of size $(\mathrm{L} 58 \times \mathrm{H} 45 \times \mathrm{B} 45 \mathrm{~cm})$ with O. niloticus juveniles (weight: $7.8 \pm 0.5 \mathrm{~g}$; length: $8.2 \pm 0.4 \mathrm{~cm}$ ). The experimental protocol, grouping of fish and treatment protocols were the same as that of fries. The concentration of $A$. hydrophila used for the challenge was $2 \times 10^{7} \mathrm{cfu} / \mathrm{ml}$ for $1 \mathrm{~h}$. The freshly dead tilapia fries and juveniles of pathogenicity and efficacy of OTC therapy 
trials were subjected to necropsy and bacteriology. Inocula from the haemorrhagic area and kidney of freshly dead fish were streaked onto Rimler-Shotts agar (RSA) plates and incubated at $35^{\circ} \mathrm{C}$ for $24-48 \mathrm{~h}$ (Austin and Austin, 2012).

\section{Relative percent survival (RPS)}

The efficacy of OTC was evaluated by calculating the relative percent survival (RPS) for OTC feed and bath treatments as per (Amend, 1981)

RPS $=1 \quad\left[\frac{\text { Percent mortality in treated group }}{\text { Percent mortality in control group }}\right] \times 100$

\section{Statistical analysis}

The results of each experiment are expressed as mean \pm standard deviation and analyzed by one-way analysis of variance (ANOVA) using Microsoft excel version 2010 to test the significance of difference between the control and experimental groups. Comparison of mean values was done by Duncan's Multiple Range Test (Duncan, 1955). Probability level of 0.05 was used to find out the significance in all cases.

\section{Results and Discussion}

Phenotypic characterization and antibiotic sensitivity of Aeromonas hydrophila $\mathrm{BBT}_{4} \mathrm{~K}_{3}$

The Vitek 2 compact system identified the bacterial strain as A. hydrophila on the basis of phenotypic characterization (Table 1). This strain was resistant to amoxyclav, clindamycin, erythromycin and vancomycin, and sensitive to chloramphenicol, ciprofloxacin, co-trimoxazole, gatifloxacin, gentamicin, nitrofurantoin, oxytetracyline and sulphafurazole (Table 2).
MIC and MBC of OTC against Aeromonas hydrophila $\mathrm{BBT}_{4} \mathrm{~K}_{3}$

The MIC and MBC of OTC against $A$. hydrophila by classical broth dilution method were $12.5 \mu \mathrm{g} / \mathrm{ml}$ and $25.0 \mu \mathrm{g} / \mathrm{ml}$, respectively. The MIC of OTC by Tetracycline Ezy MIC ${ }^{\text {TM }}$ strip method was $8 \mu \mathrm{g} / \mathrm{ml}$ (Table 3 ).

\section{Pathogenicity of Aeromonas hydrophila} $\mathrm{BBT}_{4} \mathrm{~K}_{3}$ on tilapiafries and juvelines

The abraded and challenged monosex $O$. niloticus fries were weak and lying at the tank bottom. They showed abnormal movement, loss of scales at the abraded area, skin peeling with haemorrhagic lesion, pale gills, haemorrhages in the opercular region, fin rot, tail rot, reddening and darkening of the body colour. Aeromonas hydrophila $\mathrm{BBT}_{4} \mathrm{~K}_{3}$ caused $55 \pm 7 \%$ and $20 \%$ mortalities in $O$. niloticus fries at $2 \times 10^{7} \mathrm{cfu} / \mathrm{ml}$ and $2 \times 10^{6}$ $\mathrm{cfu} / \mathrm{ml}$, respectively (Fig. 1). The $\mathrm{LD}_{50}$ value was close to $2 \times 10^{7} \mathrm{cfu} / \mathrm{ml}$ for fries. Five percent mortality was noticed in abraded control group. The abraded fish were lethargic initially and recovered within 7 days, except the wound healing.

In challenged $O$. niloticus juveniles, lethargy, abnormal behaviour, wandering around the corners, resting at the bottom and vertical swimming were observed. Cent percent mortality was noted within $12 \mathrm{~h}$ of injection at $1.2 \times 10^{8}$ cells of $A$. hydrophila/fish.

No mortalities were observed in stocks injected with $1.2 \times 10^{7}, 1.2 \times 10^{6}, 1.2 \times 10^{5}$ and $1.2 \times 10^{4} \mathrm{cfu} / \mathrm{fish}$, but the fish were weak and lying at the bottom of the tank. Inflammation and haemorrhages were seen at the injected site. No mortalities were noticed in saline injected control group. The $\mathrm{LD}_{50}$ value of $A$. hydrophila $\mathrm{BBT}_{4} \mathrm{~K}_{3}$ was estimated to be $6 \times 10^{7}$ cfu/fish. 


\section{Efficacy of OTC therapies}

The mortalities recorded during the different periods of treatment regimes in abraded monosex $O$. niloticus fries challenged with $A$. hydrophila, and subsequently fed OTC feed for 10 days are presented in figure 2. On day 1 post-abrasion and bacterial challenge, 2.8$6.7 \%$ mortalities were noticed in fish. During the disease progression period, i.e., on day 8 , 8.6-11.4\% mortalities were noticed in challenged groups. At the end of 10 day OTC feed treatment regime, i.e., on day 18 , the mortalities noticed in abraded, challenged and fed with control feed (group 3); abraded, challenged and fed with OTC feed (group 4), and positive control groups were 30.0, 14.2, and $2.8 \%$, respectively. At the end of the experimental period (day 39), the highest mortality $(36.7 \%)$ was observed in abraded, challenged and control feed fed fish. In OTC fed group, the observed mortality was $17.1 \%$. The RPS was found to be 53.3. Significant differences existed among all the treatment groups $(P<0.05)$.

The results on the effect of OTC bath therapy are presented in figure 3. After the disease progression period, i.e., on day 8, 18-19\% mortalities were noticed challenged groups. On day 12, i.e., at the end of OTC bath treatment regime, $23.8 \%$ and $20.9 \%$ mortalities were observed in untreated and OTC treated fish, respectively. No further mortalities were recorded during the posttreatment period (day 12-33). The RPS was 12. Significant differences existed among all the treatment groups $(P<0.05)$.

The abraded and challenged $O$. niloticus juveniles were observed to be weak, hanging and/or lying at the bottom of the tank. They showed erratic movement, loss of scales, skin peeling with haemorrhagic lesion, pale gills, haemorrhages in the opercular region, reddening in the pectoral fin base region, tail rot and darkened body colour. At the end of 10 day OTC treatment regime, 66.7\% mortality was noticed compared $80 \%$ in control. The total mortalities at the end of experiment in control and OTC feed fed groups were 90 and $66.7 \%$, respectively (Fig. 4). The RPS was 25.9. Significant differences existed among all the treatment groups $(P<0.05)$.

The wound healing at the abraded area was faster in OTC treated groups compared to control. The mortalities recorded in OTC oral therapy $(17.1 \%)$ were significantly lower than the bath therapy (23.8\%) in tilapia fries. Samples from the affected haemorrhagic area as well as the kidney of freshly dead and moribund fish of the A. hydrophila $\mathrm{BBT}_{4} \mathrm{~K}_{3}$ challenged fish yielded typical yellow colonies on RSA plates after $24 \mathrm{~h}$ of incubation at $35^{\circ} \mathrm{C}$. The isolated bacteria were identified as $A$. hydrophilaby conventional biochemical tests. Internally, pale kidney, liquefaction, discoloration and haemorrhages of the internal organs were observed in the abraded and challenged fish stocks.

Aeromonas hydrophila has been consistently associated with diseases or multiple of infections among variety of food fish throughout the world (Noga, 2010; Austin and Austin, 2012). Antibiotics are the treatment of choice to control the bacterial diseases. Rey et al., (2009) opined that determination of lethal dose of the bacterium before the experimental challenge is advantageous for successful experiment and induction of clinical signs and symptoms. Accordingly, in abrasion-bath treatment 20-55\% mortalities in A. hydrophila challenged tilapia fries at $2 \times 10^{6}-2 \times 10^{7} \mathrm{cfu} / \mathrm{ml}$ were recorded. The mortality rate in challenged tilapia varied in different trials possibly due the varying physiological status of the experimental fish. The results corroborate Schlotfeldt and Alderman (1995), who noted varying effects of $A$. hydrophila 
infection on fish. According to the degree of virulence (Mittal et al., 1980) and on the basis of lethal dose values $\left(2 \times 10^{7} \mathrm{cfu} / \mathrm{ml}\right.$ for fries and $6 \times 10^{7} \mathrm{cfu} / \mathrm{fish}$ for juveniles) the $A$. hydrophila $\mathrm{BBT}_{4} \mathrm{~K}_{3}$ was found to be moderately virulent to tilapia with an ability to cause systemic infection. Nevertheless, some strains of A. hydrophila clearly behave as primary pathogen (Noga, 2010; Austin and Austin, 2012).

Fig.1 Pathogenicity of Aeromonas hydrophila $\mathrm{BBT}_{4} \mathrm{~K}_{3}$ on monosex Oreochromis niloticus fries by abrasion-bath treatment. Control: Abraded and unchallenged

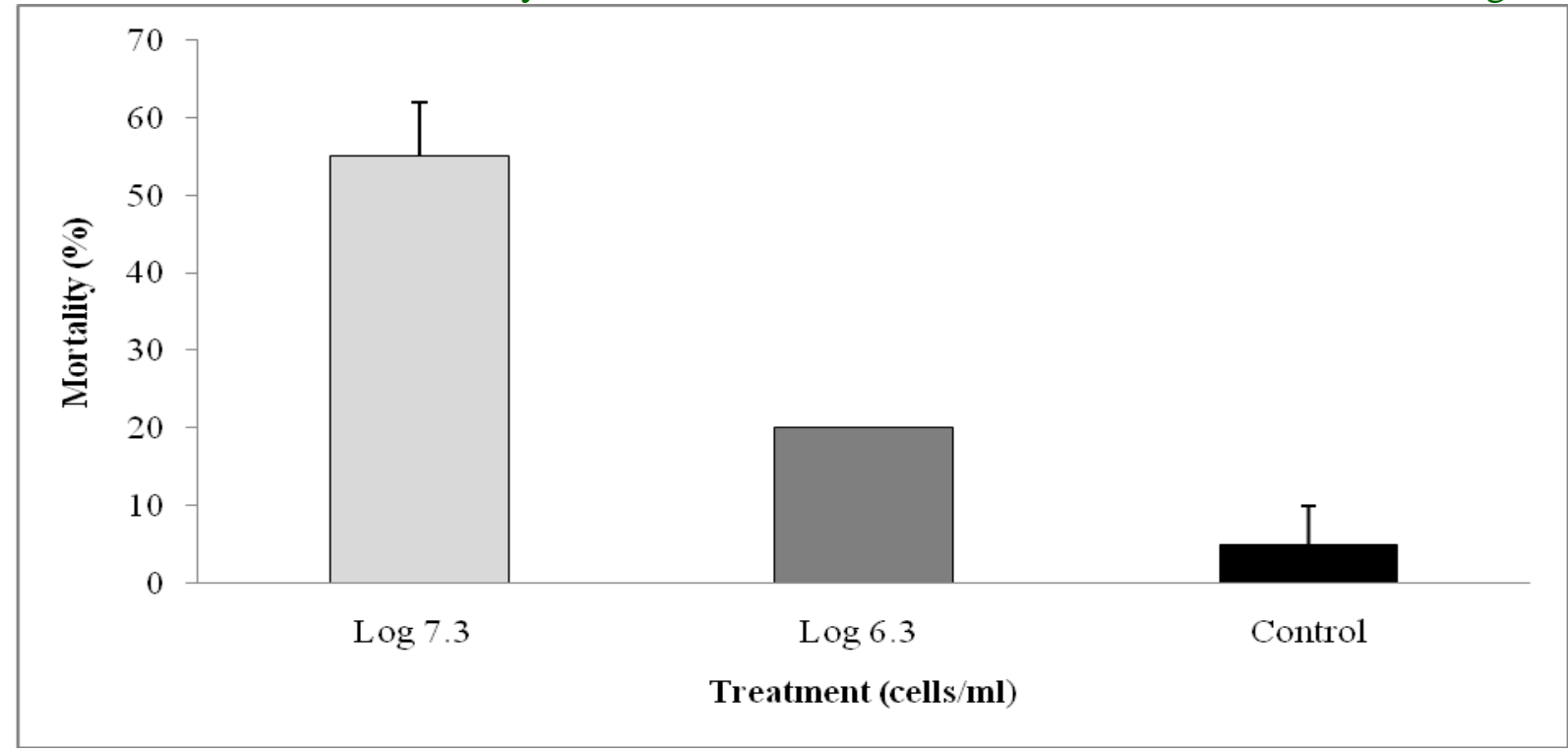

Fig.2 Effect of 10 days OTC feeding on the abraded (A) monosex Oreochromis niloticus fries challenged (C) with Aeromonas hydrophila. Note: No mortality was noted in negative control.

Positive control: Abraded and unchallenged tilapia fries. *: Bars sharing asterisk $(*)$ differ significantly $(P<0.05)$

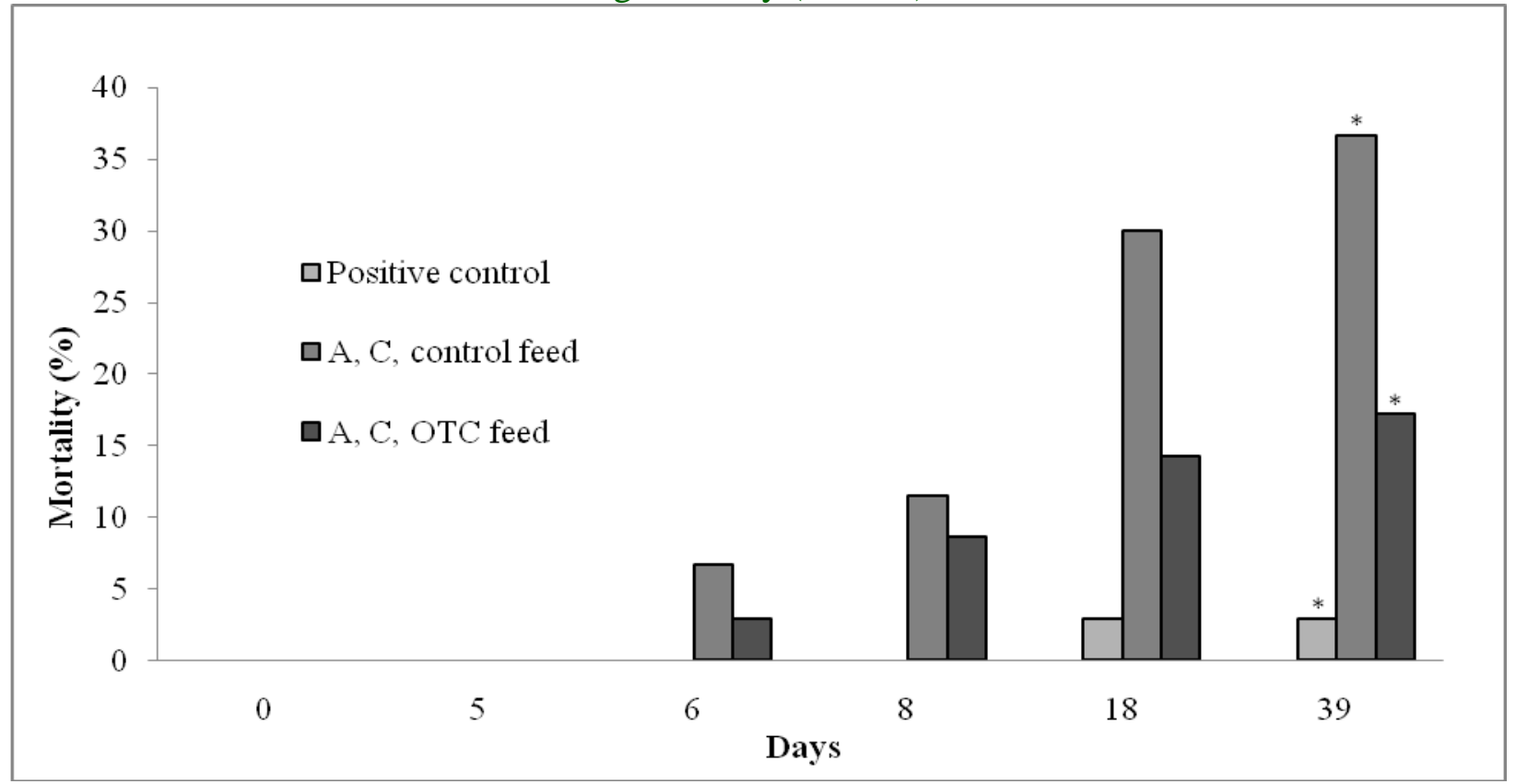


Fig.3 Effect of 4 days OTC (0 and $20 \mathrm{mg} / \mathrm{l})$ bath treatment on the abraded (A) monosex Oreochromis niloticus fries challenged (C) with Aeromonas hydrophila $\mathrm{BBT}_{4} \mathrm{~K}_{3}$. Note: No mortality was noted in negative control. Positive control: Abraded and unchallenged tilapia fries.

*: Bars sharing asterisk $(*)$ differ significantly $(P<0.05)$

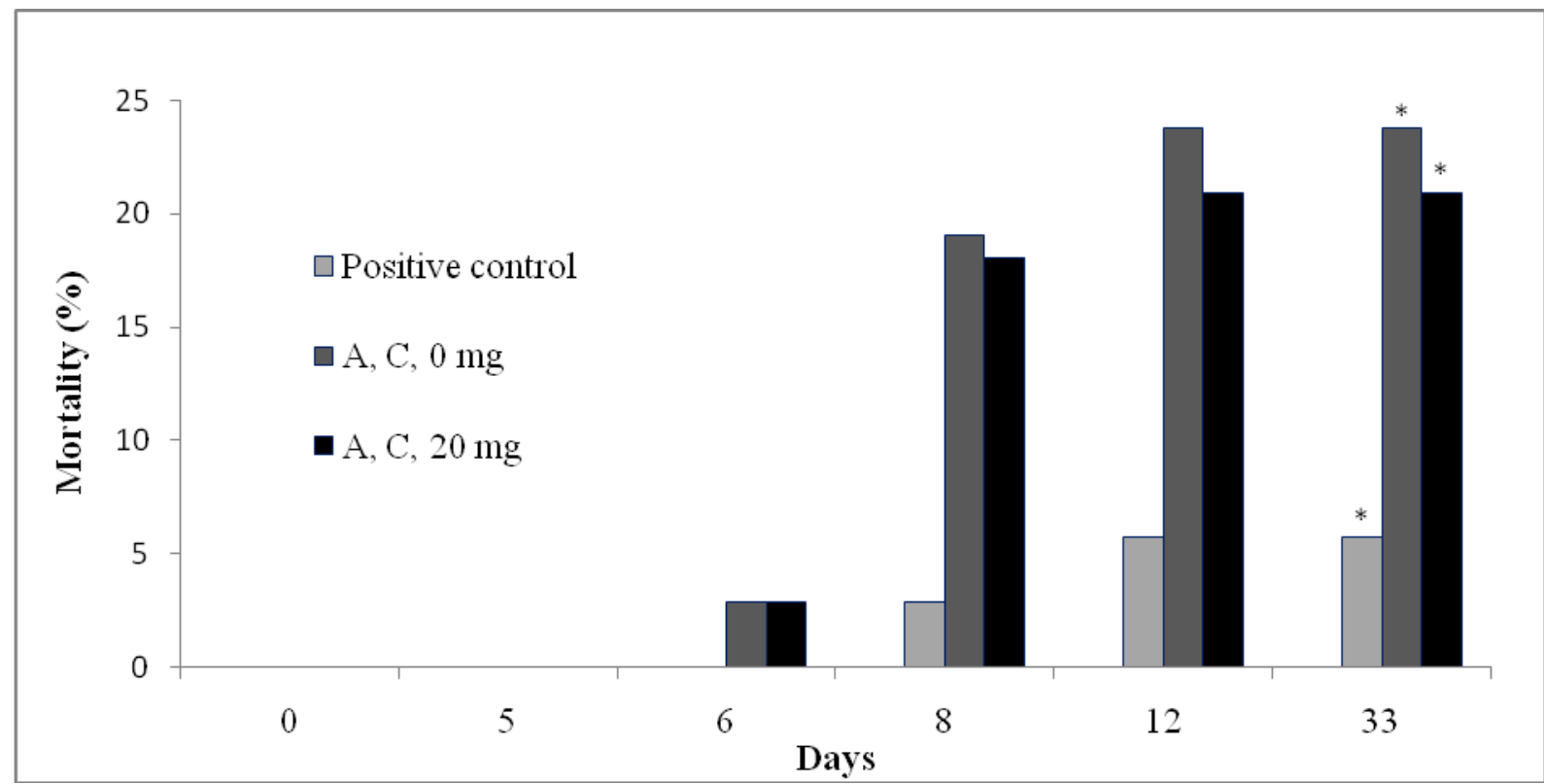

Fig.4 Effect of 10 days OTC feeding on the abraded (A) Oreochromis niloticus juveniles challenged (C) with Aeromonas hydrophila $\mathrm{BBT}_{4} \mathrm{~K}_{3}$. Note: No mortality was noted in negative control. Positive control: Abraded and unchallenged tilapia juveniles. *:

Bars sharing asterisk $(*)$ differ significantly $(P<0.05)$

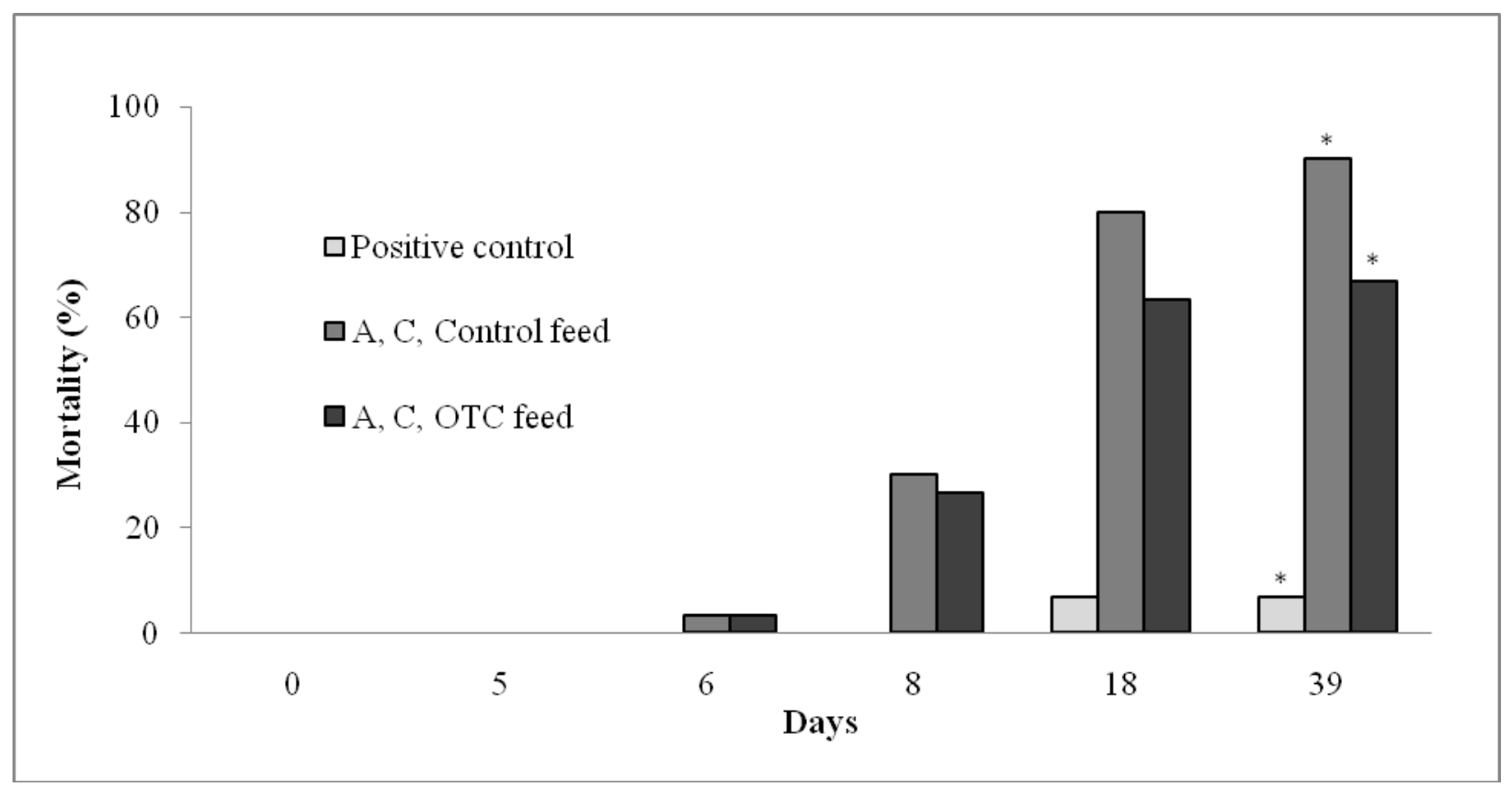


Table.1 Phenotypic characterization of fish pathogenic Aeromonas hydrophila $\mathrm{BBT}_{4} \mathrm{~K}_{3}$ by Vitek 2 compact system

\begin{tabular}{|c|c|}
\hline Phenotypic characteristics & Aeromonas hydrophila $\mathrm{BBT}_{4} \mathrm{~K}_{3}$ \\
\hline 5-Keto D-gluconate (5KG) & - \\
\hline Adonitol (ADO) & - \\
\hline Ala-Phe-Pro-arylamidase (APPA) & - \\
\hline Alpha-galactosidase (AGAL) & - \\
\hline Alpha-glucosidase (AGLU) & - \\
\hline Beta-alanine arylamidasepNA (BAlap) & - \\
\hline Beta-galactosidase (BGAL) & + \\
\hline Beta-glucuronidase (BGUR) & - \\
\hline Beta-glucosidase (BGLU) & - \\
\hline Beta-xylosidase (BXYL) & - \\
\hline Citrate (sodium) (CIT) & - \\
\hline Coumarate (CMT) & + \\
\hline D-Cellobiose (dCEL) & - \\
\hline D-Glucose (dGLU) & + \\
\hline D-Maltose (dMAL) & + \\
\hline D-Mannitol (dMAN) & + \\
\hline D-Mannose (dMNE) & + \\
\hline D-Sorbitol (dSOR) & - \\
\hline D-Tagatose (dTAG) & - \\
\hline D-Trehalose (dTRE) & + \\
\hline Ellman (ELLM) & + \\
\hline Fermentation/ glucose (OFF) & + \\
\hline Gamma-glutamyltransferase (GGT) & - \\
\hline Glu-Gly-Arg-arylamidase (GGAA) & + \\
\hline GlutamylarylamidasepNA (AGLTp) & - \\
\hline Glycine arylamidase (GlyA) & - \\
\hline $\mathrm{H}_{2} \mathrm{~S}$ production $\left(\mathrm{H}_{2} \mathrm{~S}\right)$ & + \\
\hline L Pyrrolydonyl-arylamidase (PyrA) & - \\
\hline L-Arabitol (IARL) & - \\
\hline L-Histidine assimilation (IHISa) & - \\
\hline Lipase (LIP) & - \\
\hline L-Lactate alkalinisation (ILATk) & + \\
\hline L-Lactate assimilation (ILATa) & - \\
\hline L-Malate assimilation (IMLTa) & - \\
\hline L-Prolinearylamidase (ProA) & + \\
\hline Lysine decarboxylase (LDC) & - \\
\hline Malonate (MNT) & - \\
\hline O/129 Resistance (O129R) & + \\
\hline Orinithine decarboxylase (ODC) & - \\
\hline Palatinose (PLE) & + \\
\hline Phosphatase (PHOS) & - \\
\hline Saccharose/Sucrose (SAC) & + \\
\hline Succinate alkalinisation (SUCT) & + \\
\hline Tyrosine arylamidase (TyrA) & + \\
\hline Urease (URE) & - \\
\hline$\beta$-N-acetyl-galactosaminidase (NAGA) & - \\
\hline$\beta$-N-Acetyl-glucosaminidase (BNAG) & + \\
\hline
\end{tabular}


Table.2 Antibiotic sensitivity of fish pathogenic Aeromonas hydrophila $\mathrm{BBT}_{4} \mathrm{~K}_{3}$

\begin{tabular}{lll}
\hline Antibiotics $(\mu \mathrm{g} / \mathrm{disc})$ & Zone of inhibition in $\mathrm{mm}$ & Antibiogram \\
\hline Amoxyclav (30) & 7 & $\mathrm{R}$ \\
Chloramphenicol (30) & 32 & $\mathrm{~S}$ \\
Ciprofloxacin (5) & 26 & $\mathrm{~S}$ \\
Clindamycin (2) & 7 & $\mathrm{R}$ \\
Co-trimoxazole (25) & 21 & $\mathrm{~S}$ \\
Erythromycin (15) & 11 & $\mathrm{R}$ \\
Gatifloxacin (5) & 22 & $\mathrm{~S}$ \\
Gentamicin (10) & 18 & $\mathrm{~S}$ \\
Nitrofurantoin (300) & 21 & $\mathrm{~S}$ \\
Oxytetracycline (30) & 18 & $\mathrm{~S}$ \\
Sulphafurazole (300) & 28 & $\mathrm{~S}$ \\
Vancomycin (30) & 9 & $\mathrm{R}$ \\
\hline
\end{tabular}

Table.3 Minimal inhibitory concentration (MIC) and minimal bactericidal concentration (MBC) of oxytetracycline against Aeromonas hydrophila $\mathrm{BBT}_{4} \mathrm{~K}_{3}$

\begin{tabular}{lll}
\hline Methods & MIC $(\mu \mathrm{g} / \mathrm{ml})$ & MBC $(\mu \mathrm{g} / \mathrm{ml})$ \\
\hline Broth dilution & 12.50 & 25.00 \\
Ezy MIC $^{\mathrm{TM}}$ & 8.00 & - \\
\hline
\end{tabular}

The in-vitro drug susceptibility tests contribute to understand and evaluate the drug resistance of the pathogen, and help to take treatment decisions in controlling the disease. The $\beta$-haemolytic $A$. hydrophilastrain isolated from the kidney of septicemic $O$. niloticus was sensitive to OTC and exhibited varying degrees of resistance to other antibiotics. The results of this study are in agreement with few earlier studies (Awan et al., 2009; Stratev et al., 2013) but contradictory to other observations (Dias et al., 2012; Bharathkumar and Abraham, 2014). Aeromonas spp were, in general, sensitive to tetracycline, chloramphenicol, nitrofurantoin, amikacin, gentamicin, cefazolin, tobramycin, cephalexin, cefuroxime, ceftrioxone, cephalothin, cefoxitin, cefotaxime, colistinsulfate, ciprofloxacin and trimethoprim-sulfamethoxazole (Awan et al., 2009). The MICs values of $12.5 \mu \mathrm{g} / \mathrm{ml}$ and 8 $\mu \mathrm{g} / \mathrm{ml}$ recorded respectively by broth dilution and Ezy MIC ${ }^{\mathrm{TM}}$ strip methods, and the MBC value of $25 \mu \mathrm{g} / \mathrm{ml}$ also advocated the susceptibility of $A$. hydrophila to OTC.
The variations in MIC values could be attributed to the use of solid and liquid media, which generate numerically different MIC values (CLSI, 2006a, b). The MIC for OTC has been recorded for several A. hydrophila and other motile aeromonads around the world. For example, Aeromonas strains exhibited MICs in the range of $>0.06-256 \mathrm{mg}$ OTC/ml (Guzand Kozinska, 2004). Also Aeromonas strains with high MIC values for OTC ranging from $50 \mu \mathrm{g} / \mathrm{ml}$ (Neowajh et al., 2015) to $600 \mu \mathrm{g} / \mathrm{ml}$ (Singh et al., 2009) have been reported. Conceivably, the high MIC values for OTC may cause problems for chemotherapy in the future.

The present study aimed at the control $A$. hydrophila infection at the recommended dosage of OTC by appropriate means (FDACVM, 2007; WGADCB, 2011). It was observed that the mortalities due to $A$. hydrophila challenge were more during the initial 3-5 days of infection in fries, which reduced drastically in the later phase. These findings corroborate the observations made in 
tilapia hybrids (Rey et al., 2009), where changes in liver, kidney, spleen, intestine, muscle, stomach and brain were noticed up to 3 day post-infection to A. hydrophila. At the end of 7 days post-challenge the bacteria got eliminated from the major tissues. Similar results were also noted in A. hydrophila challenged Labeorohita (Das et al., 2014). During the OTC therapy, it was observed that the recovery rate of the experimentally infected fish varied with OTC dose and the method of application. In OTC feed trial, $14.2 \%$ mortalities were observed during the 10 days treatment regime, despite the poor intake of medicated feed initially by the abraded and challenged fish. On the other hand, 20.9\% mortalities were noticed during the 4 days treatment regime of OTC bath treated group. The observations on the significantly high mortalities during the posttreatment regime in bath $(23.8 \%)$ therapy (20 $\mathrm{mg}$ OTC/l) than in feed (17.1\%) therapy (60 $\mathrm{mg}$ OTC/kg biomass/day) suggested that the treatment of fish with OTC feed is better than the bath treatment. The results were also justified from the calculations of RPS, which yielded the highest RPS (53.2) for oral therapy and the lowest (12.0) for bath therapy.

In the present study the $O$. niloticus juveniles were found to be susceptible to A. hydrophila infection than the fries. The abraded $O$. niloticus fries experienced significantly low moralities (37\%) and high RPS (53.2) compared to abraded juveniles (90\%) and low RPS (25.9) when challenged with $A$. hydrophila. It has been demonstrated that the effects of A. hydrophila infection in fish can vary according to the resistance to infection (Schlotfeldt and Alderman, 1995) and with the size of the animal (Oliveira et al., 2011). The present results corroborate the observations of Haque et al., (2014), who demonstrated the effectiveness of $2 \mathrm{~g}$ OTC $/ \mathrm{kg}$ diet in reducing the bacterial load of fish under artificial culture condition.
The main advantage of oral therapy is that it does not stress the fish. Nevertheless, Floyd (1993) documented that bath treatment was effective in controlling only the external infection such as fin rot, bacterial gill disease, superficial fungal infections and ectoparasitic infestations in fish. Bath treatment was reportedly not as effective as feed or other treatment methods, particularly for systemic infections, because of generally poor internal absorption of the antibiotic being used (Sekkinand Kum, 2011). The dosage required for treatment with a medicated feed depends on the original level of active ingredient $/ \mathrm{kg}$ fish bw. It is obvious that the majority of the infected fish do not eat. Also the fish do not effectively metabolize antibiotics and will pass them largely unused back into the environment in the faeces. It has been estimated that $75 \%$ of the antibiotics fed to fish are then put into the water through excretion (Burridge et al., 2010; Romero et al., 2012). Hence, bath therapy should be considered only when the majority of the fish are not eating and fish should be switched to oral medication as soon as they resume eating.

In India antibiotic sales and usage are not regulated except the recent guidelines on the registration of antibiotic free aquadrugs by the Coastal Aquaculture Authority of India (http://www.caa.gov.in/). Till date, no veterinary prescriptions are required in India for the use of antibiotics in aquatic animals. The safety and efficacy of FDA approved antibiotics including OTC are not available or poorly understood on fish cultured in India. The present study demonstrated that OTC was effective in controlling the A. hydrophila infection in tilapia through oral and bath therapies under Indian conditions, with OTC oral therapy being the most effective. Since OTC is one of the FDA approved antibiotics for treating bacterial diseases of temperate and warm water finfish, the responsible use of 
OTC is, therefore, recommended for the control of Aeromonas infection in tilapia. The results of the present study would provide some baseline date on the efficacy of OTC to the policy makers and regulatory authorities of Indian aquaculture.

\section{Acknowledgements}

The research work was supported by the Indian Council of Agricultural Research, Government of India, New Delhi under the All India Network Project on Fish Health. The authors thank the Vice-Chancellor, West Bengal University of Animal and Fishery Sciences, Kolkata for providing necessary infrastructure facility to carry out the work.

\section{Declaration of Interest}

The authors declare that there is no conflict of interest.

\section{References}

Adikesavalu, H., Patra, A., Banerjee, S., Sarkar, A. and Abraham, T.J. 2015. Phenotypic and molecular characterization and pathology of Flectobacillus roseus causing flectobacillosis in captive held carp Labeorohita (Ham.) fingerlings. Aquaculture, 439: 60-65.

Amend, D.F. 1981.Potency testing of fish vaccines. Developments in biological standardization, 49: 447.

Austin, B. and Austin, D.A. 2012. In: Bacterial Fish Pathogens: Disease of Farmed and Wild Fish. $5^{\text {th }}$ edn, pp. 457. Praxis Publication Ltd, UK.

Awan, M.B., Maqbool, A., Bari, A. and Krovacek, K. 2009. Antibiotic susceptibility profile of Aeromonas spp. isolates from food in Abu Dhabi, United Arab Emirates. The New Microbiologica, 32: 17-23.
Bharathkumar, G. and Abraham, T.J. 2011. Antibiotic susceptibility of Gram negative bacteria isolated from freshwater fish hatcheries of West Bengal, India. Indian Journal of Fisheries, 58: 135-138.

Burridge, L., Weis, J.S., Cabello, F., Pizarro, J. and Bostick, K. 2010. Chemical use in salmon aquaculture: A review of current practices and possible environmental effects. Aquaculture, 306: 7-23.

CLSI, 2006a. Methods for Antimicrobial Disk Susceptibility Testing of Bacteria Isolated from Aquatic Animals. Clinical and Laboratory Standards Institute, Document M42-A, Wayne, Pennsylvania, USA.

CLSI, 2006b. Methods for Broth Dilution Susceptibility Testing of Bacteria Isolated from Aquatic Animals, Clinical and Laboratory Standards Institute, Document M49-A, Wayne, Pennsylvania, USA.

CLSI, 2012. Performance Standards for Antimicrobial Susceptibility Testing. Clinical and Laboratory Standards Institute, Document M100-S22, Wayne, Pennsylvania, USA.

Collins, C.H., Lyne, Patricia M., Grange, J. M. and Falkinham, J.O. 2004. In: Microbiological Methods, $8^{\text {th }}$ edn, pp. 456. Arnold, London.

Das, S., Mishra, J., Mishra, A., Mahapatra, K.D., Saha, J.N. and Sahoo, P.K. 2014.Establishment of route of challenge and tissue level persistence study of Aeromonas hydrophila infection in rohu, Labeorohita for running a selection programme. International Journal of Fisheries and Aquatic Studies, 1: 216.

Dias, C., Mota, V., Martinez-Murcia, A. and Saavedra, M.J. 2012. Antimicrobial resistance patterns of Aeromonas spp. Isolated from ornamental fish. Journal 
of Aquaculture Research and Development, 3: 1-4.

Duncan, D.B. 1955. Multiple range and multiple " $F$ " test. Biometrics, 11: 1-42.

FAO, 2012. The State of World Fisheries and Aquaculture. FAO fisheries and aquaculture department.

FDA-CVM. 2007. Aquaculture website. FDA-CVM.

Floyd, R.F. 1993In: The Veterinary Approach to Game Fish. pp. 395. Pergamon Press, UK.

Goharrizi, L.Y., Zorriehzahra, M.E.J. and Adel, M. 2015.The study on effect of temperature stress on occurrence of clinical signs caused by Aeromonas hydrophila in Capoeta damascina in invitro condition. Advances in Animal and Veterinary Sciences, 3: 406.

Guz, L. and Kozinska, E. 2004. Antibiotic susceptibility of Aeromonas hydrophila and A. sobria isolated from farmed carp (Cyprinus carpio L). Bulletin of the Veterinary Institute in Pulawy, 48: 391395.

Haque, S.S., Reza, M.S., Sharker, M.R., Rahman, M.M. and Islam, M.A. 2014. Effectiveness of oxytetracycline in reducing the bacterial load in rohu fish (Labeo rohita, Hamilton) under laboratory culture condition. Journal of Coastal Life Medicine, 2: 259-263.

Hatha, A.A.M., Vivekanandhan, A.A., Joice, G.J. and Christol. 2005. Antibiotic resistance pattern of motile aeromonads from farm raised fresh water fish. International Journal of Food Microbiology, 98: 131-134.

Hernandez, S.P. 2005. Responsible use of antimicrobials in aquaculture. FAO Fisheries Technical Paper, 469: 1-97.

http://www.caa.gov.in/

Little, D.C., Murray, F.J., Azim, E., Leschen, W., Boyd, K., Watterson, A. and Young, A. 2008. Options for producing a warm water fish in the UK: limits to
'Green Growth'? Trends in Food Science and Technology, 19: 255-264.

Mittal, K.R., Lalonde, G., Leblanc, D., Olivier, G. and Lallier, R. 1980.Aeromonas hydrophila in rainbow trout: relation between virulence and surface characteristics. Canadian Journal of Microbiology, 26: 15011503.

Neowajh, S., Hossain, M.M.M., Kholil, I., Mona, S.N., Islam, S. and Kabi, M. 2015. Potentiality of selected commercial antibiotics challenged with Aeromonas sp. Immunology and Infectious Diseases, 3: 11-15.

Noga, E.J. 2010. In: Fish Disease: Diagnosis and Treatment. $2^{\text {nd }}$ edn, pp. 536. John Wiley and Sons Publications, Ames, Iowa.

Noor El Deen, A.E., Dorgham, S.M., Hassan, A.H.M. and Hakim, A.S. 2014. Studies on Aeromonas hydrophila in cultured Oreochromis niloticus at Kafr El Sheikh Governorate, Egypt with reference to histopathological alterations in some vital organs. World Journal of Fish and Marine Sciences, 6: 233-240.

Oliveira S.R., Souza R.T.Y.B., Brasil E.M., Andrade J.I.A., Nunes É.S.S., Ono E.A. and Affonso E.G. 2011. $\mathrm{LD}_{50}$ of the bacteria Aeromonas hydrophila to matrinxã, Brycon amazonicus. Acta Amazonica, 41: 321-326.

Reed, L.J. and Muench, H. 1938.A simple method of estimating fifty per cent endpoints. American Journal of Hygiene, 27: 493.

Rey, A., Verjan, N., Ferguson, H.W. and Iregui, C. 2009. Pathogenesis of Aeromonas hydrophila strain KJ99 infection and its extracellular products in two species of fish. Veterinary Record, 164: 493-499.

Romero, J., Feijoo, C. G. and Navarrete, P. 2012.Antibiotics in Aquaculture - Use, Abuse and Alternatives. In: Health and 
Environment in Aquaculture, pp.159.

Schlotfeldt, H.J. and Alderman, D.J.A. 1995. Practical guide for the freshwater fish farmer. Bulletin of European Association for Fish Pathologists, 15: 134-157.

Schmidt, L.J., Gaikowski, M.P., Gingerich, W.H., Dawson, V.K. and Schreier, T.M. 2007. An Environmental Assessment of the Proposed Use of Oxytetracycline-Medicated Feed in Freshwater Aquaculture. (U.S. Geological Survey, Biological Resources Division, and Upper Midwest Environmental Sciences Center, Wisconsin).

Sekkin, S. and Kum, C. 2011. Antibacterial Drugs in Fish Farms: Application and Its Effects, Recent Advances in Fish Farms.

Singh, A.K., Rathore, G., Singh, V., Mani, I.,
Singh, R.K., Mishra, S.K., Mishra, B.N. and Verma, O.P. 2009. Bacterial resistance to oxytetracycline in different life stages of Indian freshwater carp aquaculture system. International Journal of Microbiology Research, 1: 25-34.

Stratev, D., Vashin. and Daskalov, H. 2013. Antimicrobial resistance of $\beta$ haemolytic Aeromonas hydrophila strains isolated from rainbow trouts (Oncorhynchus mykiss). Bulgarian Journal of Veterinary Medicine, 16: 289-296.

WGADCB, 2011.Guide to Using Drugs, Biologics, and Other Chemicals in Aquaculture. Working Group on Aquaculture Drugs, Chemicals and Biologics, American Fisheries Society, Bethesda, Maryland.

\section{How to cite this article:}

Beryl Julinta, R., Anwesha Roy, Jasmine Singha, T. Jawahar Abraham and Patil, P.K. 2017. Evaluation of Efficacy of Oxytetracyclineoral and Bath Therapies in Nile Tilapia, Oreochromis niloticus against Aeromonas hydrophila Infection. Int.J.Curr.Microbiol.App.Sci. 6(7): 62-76. doi: https://doi.org/10.20546/ijcmas.2017.607.008 